\title{
Body fat evaluation in Colombian Paso horses: body condition score and morphometric and ultrasound measurements
}

\section{Avaliação da gordura corporal em equinos Paso colombianos: escore de condição corporal e medidas morfométricas e ultrassonográficas}

\author{
Angélica María Zuluaga Cabrera $^{1}$ (D); Nathalia María del Pilar Correa Valencia ${ }^{1}$ \\ ${ }^{1}$ Universidad de Antioquia, Facultad de Ciencias Agrarias, Escuela de Medicina Veterinaria, Grupo de Investigación Centauro, \\ Medellín, Colombia
}

\begin{abstract}
The body condition score (BCS) is insufficient in determining the amount of body fat in horses, thus defining obesity. Measurement of the subcutaneous fat thickness (SFT) by ultrasonography should be considered as an appropriate method in the definition of fat distribution at different body locations in horses. Therefore, this study aimed to 1) characterize the SFT in three different anatomical locations (i.e. neck, lumbar region, and gluteal region); 2) evaluate the relationship between BCS and SFT; 3) determine the influence of gender, weight, age, and gait on BCS and SFT measurements, and 4) explore the agreement between the morphometric measurements [i.e. body mass index (BMI), girth circumference: height at withers ratio (GC: HW), neck circumference: height at withers ratio (NC: HW)], and BCS and SFT in a population of Colombian Paso Horses (CPHs). The Henneke's body condition scoring was applied to 69 adult CPHs, selected using a convenience sampling. Additionally, BMI, GC: HW, and NC: HW were calculated. Body fat percentage (BF\%) was calculated by ultrasound measurement of the SFT in the neck, lumbar region, and gluteal region. The BF\% in the CPHs was $6.4 \pm 1.1$. The GC: HW, NC: $\mathrm{HW}$, and BMI were not predictors of the BF\% or BCS, and neither gender nor gait was decisive in the definition of fattening in the study animals, although age and weight were determining variables. According to our results, ultrasound is an adequate tool to calculate the $\mathrm{BF} \%$ of the $\mathrm{CPHs}$. However, it must be accompanied by Henneke's BCS assessment.
\end{abstract}

Keywords: Adiposity. Body fat. Paso-horse. Ultrasound.

\section{RESUMO}

O escore de condição corporal (ECC) é insuficiente para a determinação da quantidade de gordura corporal em cavalos e para a definição da obesidade. A mensuração da espessura da gordura subcutânea (EGS) por ultrassonografia pode ser considerada um método apropriado para a definição da distribuição de gordura em diferentes locais do corpo em cavalos. Portanto, este estudo teve como objetivo 1) caracterizar a EGS em três diferentes localizações anatômicas (pescoço, região lombar e região glútea), 2) avaliar a relação entre ECC e EGS, 3) determinar a influência de gênero, peso, idade e marcha nas medidas ECC e EGS e, 4) explorar a concordância entre as medidas morfométricas [i.e. índice de massa corporal (IMC), razão da circunferência da cintura:altura da cernelha (CC:AC), razão da circunferência do pescoço:altura da cernelha (CP:AC)], ECC e EGS em uma população de Cavalos Paso colombiano (CPCs). A pontuação da condição corporal de Henneke foi aplicada a 69 CPCs adultas, selecionadas por amostragem de conveniência. Além disso, IMC, CC:AC e CP:AC foram calculados. O percentual de gordura corporal (\%GC) foi calculado por meio da ultrassonografia da EGS no pescoço, região lombar e região glútea. A \%GC nas CPCs foi de 6,4 $\pm 1,1$. O CC:AC, CP:AC e IMC não foram preditores da \%GC ou ECC, e nem o gênero nem a marcha foram decisivos na definição de obesidade nos animais do estudo, embora a idade e o peso fossem variáveis determinantes. De acordo com nossos resultados, o ultrassom é um recurso adequado para calcular a \%GC das CPCs. No entanto, deve ser acompanhado pela avaliação do ECC do Henneke.

Palavras-chave: Adiposidade. Grassa corporal. Cavalo Paso. Ultrassom. 


\section{Correspondence to:}

Angélica Zuluaga-Cabrera

Universidad de Antioquia, Facultad de Ciencias Agrarias,

Escuela de Medicina Veterinaria, Grupo de Investigación

Centauro

Carrera 42A \#40H sur 74, Barrio El Dorado

Envigado, Antioquia, Colombia

e-mail: angelica.zuluaga@udea.edu.co

Received: June 15, 2020

Approved: October 27, 2020

How to cite: Zuluaga Cabrera AM, Correa Valencia NMP. Body fat evaluation in Colombian Paso horses: body condition score and morphometric and ultrasound measurements. Braz J Vet Res Anim Sci. 2020;57(4):e171082. https://doi. org/10.11606/issn.1678-4456.bjvras.2020.171082

\section{Introduction}

The body condition score (BCS) is insufficient in determining the amount of body fat in horses and, therefore, in the definition of obesity (Dugdale et al., 2011a; Argo et al., 2012). Some studies in obesity-predisposed horses have determined that the Henneke's horse BCS (Henneke et al., 1983) should be adjusted according to the morphology of each breed, given the differences found in regional adiposity and the general appearance of the animals (Martin-Giménez et al., 2016a, 2016b). Henneke's BCS is an indirect method of body fat scoring that presents difficulties in differentiating an overweight and obese horse (Pearson et al., 2018) since it is not directly related to the amount of subcutaneous, cavitary, and visceral adipose tissue. Furthermore, to the authors' experience, it does not allow determination of the nutritional status of the horse.

Defining obesity in athletic horses is a priority. Obesity is a restrictive condition for sport, due to the metabolic disorders that occur and the risk of laminitis. Also, it decreases the body's ability to develop functional muscle mass, necessary when performing sports activities, predisposing the obese horse to exercise-induced pathologies. On the other hand, obesity has been linked to inflammatory changes at the articular level by biomarkers such as prostaglandin E in synovial fluid (Pearson et al., 2018). This demonstrates that the accumulation of adipose tissue implies deleterious changes in horse health.

Obesity has been traditionally evaluated through the Henneke's BCS, nuchal crest, and body mass index (BMI) (Thatcher et al., 2008). However, it is complex to determine obesity based on visual methods in obesity-predisposed and muscular breeds, or subtypes of the same breed (e.g. gait). Establishing objective body fat measurements is essential to avoid the overestimation of obesity in these breeds and individuals. Furthermore, a better understanding of fat deposition could help to understand the dynamics of lipid disorders in the horse. Consequently, body fat-objective indicators are needed to increase the precision of the assessment of body composition to highlight animals at risk of obesity-related diseases.

Measurement of the subcutaneous fat thickness (SFT) by ultrasonography has been considered an appropriate method when defining the subcutaneous distribution of adipose tissue in different body locations and as an appropriate method when monitoring the increase in subcutaneous adipose tissue in horses with phenotypically established deposition patterns, as many Andalusian horse-related breeds (Martin-Giménez et al., 2016b). This method has also been used in young animals to monitor body development during the lactation period (Hunka et al., 2014). Westervelt et al. (1976) described a high correlation between body fat percentage $(\mathrm{BF} \%)$ - measured by ultrasound of the gluteal region, and the amount of fat tissue extracted from the carcasses of horses and ponies $\left(\mathrm{r}^{2}=0.93\right)$, validating this method.

Additional ante-mortem approaches have been reported in horses to estimate general adiposity. Carter et al. (2009) determined that girth circumference: height at withers ratio (GC: $\mathrm{HW}$ ) is the most appropriate indirect measure for the evaluation of general adiposity, and that neck circumference: height at withers ratio (NC: $\mathrm{HW}$ ) is an adequate measure in the evaluation of regional adiposity of the neck. These morphometric measurements have also been used in Icelandic horses (Jensen et al., 2016), Argentinean saddlebred crossbreed, and Paso horses (Velásquez-Mosquera et al., 2016), and Portuguese Asinina de Miranda donkey breed (Quaresma et al., 2013). By dissecting white fat in pony carcasses, Dugdale et al. (2011b) confirmed that GC: HW measurement and ultrasound of retroperitoneal adipose tissue have a high predictive capacity for general body adiposity in the species. Nevertheless, to the author's knowledge, no studies on SFT in Colombian Paso horses (CPHs) are available so far in Colombia or elsewhere.

Therefore, this study aimed to 1) characterize the SFT in three different anatomical locations (i.e. neck, lumbar region, and gluteal region); 2) evaluate the relationship between BCS and SFT; 3) determine the influence of gender, weight, age, and gait on BCS and SFT measurements; and 4) explore the agreement between the morphometric measurements (i.e. body mass index - BMI, GC: HW, NC: HW), and BCS and SFT in a population of Colombian Paso Horses (CPHs). 


\section{Materials and Methods}

\section{Animals}

Sixty-nine stabled adult CPHs were selected using a convenience sampling. Animals were located in the Eastern sub-region of the Province of Antioquia (Colombia). Thirty-nine females and 30 male horses, aged 2-22 years, composed the study group. Table 1 presents an additional gait differentiation for the characterization of the study population.

\section{Body condition score assessment}

A veterinarian trained for the task assessed the BCS for the entire study population, considering the Henneke's body scoring (Henneke et al., 1983) and Carter's nuchal crest scorings (Carter et al., 2009), with a "blind" assessment of the measurements taken by ultrasound.

\section{Ultrasound measurements}

To describe a possible method to be applied in the field, animals were not shaved. Then, measurements were taken using antiseptic alcohol on clean hair. Ultrasonographic images were taken at three defined points, according to previous reports in other breeds (Martin-Giménez et al., 2018). Anatomic landmarks were identified by palpation and visual assessment, as follows: 1 ) SFT-75\% of neck length (from the base of the ear towards the dorsal edge of the scapula, in a straight line in the anatomical demarcation formed by the trapezius muscle and the nuchal ligament laminar portion); 2) SFT-lumbar region (3-cm laterally, at the L6); and, 3) SFT-gluteal region (50\% of the path between the coxal tuberosity and the greater trochanter of the femur and $5 \mathrm{~cm}$ in the direction of the sacrum). All measurements were taken in triplicate, calculating the coefficient of variation $(\mathrm{CV})$ among measurements to guarantee a mean homogeneity and representativeness (CV $\leq 20 \%$ ). The Sonoscape ${ }^{\circledR}$ A5V (SonoScape Medical Corp. China) equipment was considered, using a 7-8 MHz linear probe to measure the SFT at the neck, lumbar region, and gluteal points, and a 3.5-4.5 MHz convex probe for the gluteal muscle. All images were taken in B-mode and under the image freezing function, using the place with the highest SFT. The ultrasonographic technique was subjected to a pre-test on animals other than the study ones, to verify repeatability, reproducibility, and practicality of the method.

\section{Morphometric measurements}

Weight was measured using a weight tape for horses, as previously reported (Jensen et al., 2016). The height at the withers was measured with the horse in pedestation, locating each animal with the fore and hind limbs perpendicular to a flat floor (Martinson et al., 2014). The perimeter of the thorax and the circumference of the neck were taken surrounding the reference points (cross and the most prominent portion of the neck, respectively). Chest width was measured as the length between the scapulo-humeral joints, and the body length resulted from the measurement between the scapulo-humeral joint and the ipsilateral ischial tuberosity. All morphometric values were obtained using a conventional tape measure. The BMI was calculated according to Carter et al. (2009) [weight $(\mathrm{kg}) /$ height at the withers $\left(\mathrm{m}^{2}\right)$ ]; and, NC: HW ratio [neck circumference $(\mathrm{cm}) /$ height at the withers $\left(\mathrm{m}^{2}\right)$ ] and GC: HW ratio [thorax perimeter $(\mathrm{cm}) /$ height at the withers $\left(\mathrm{m}^{2}\right)$ ] according to Jensen et al. (2016). The BF\% was calculated according to the formula established by Kane et al. (1987) [5.47 × SFT-gluteal region $(\mathrm{cm})+2.47]$.

\section{Statistical analysis}

The data was collected in Excel spreadsheets (Microsoft Corp., Redmond, WA, USA) and then exported to Stata 16.0 (StataCorp, 2019, College Station, TX, USA) for analysis. Descriptive statistics (i.e. mean, standard deviation, minimum value, maximum value) were defined for all continuous variables. Also, a bivariate Pearson correlation analysis was performed between all variables. Since the data obtained behaved in a normal way according to the Shapiro-Wilk test $(\mathrm{p}=0.0913)$, the one-way ANOVA analysis of variance was performed to compare the means between the SFT values at the three anatomical points and Henneke's BCS. All analyses considered a significance level of $p \leq 0.05$.

\section{Results}

According to the selection of the animals of study, distribution by gender, and gait were defined (Table 1). According to age, 27 horses were between 2 and 5 years, 33 were between 6 and 10 years, and 9 horses were $>10$. Morphometric and ultrasound measurements were compiled, according to the values obtained from all the animals in the study (Table 2).

Once the horses were classified according to Henneke's BCS, the circumference of the neck, ultrasound measurements, $\mathrm{BF} \%$, and $\mathrm{BMI}$ were grouped by means and standard deviation (Table 3 ).

Neck circumference, BF\%, and BMI were found to be notoriously different when the Henneke's BCS was equal to or greater than $7 / 9$, whereas that changes between Henneke's BCS of 7/9 and 8/9 were not easily distinguishable. This pattern was repeated for Henneke's BCS of 5/9 and 6/9 (Table 3). The behavior of the GC: HW ratio according to Henneke's BCS, showed a progressive and uniform increase 
concerning the BCS (low SD). In contrast, the NC: HW ratio showed no notable changes in the 5/9 score (Table 4).

When the results of GC: HW, NC: HW, and BF\%, according to gait and gender were obtained, we found that GC: HW in females was greater than or equal to the same indicator in males, independent of their gait. In contrast, the NC: HW was higher for males than for females in all gaits. Additionally, BF\% did not show a specific trend according to gait or gender (Table 5), nor did it seem to correspond to the GC: HW or NC: HW ratios.

According to the bivariate Pearson analysis ( $p \leq 0.05$ ), a correlation between the Henneke's BCS, BMI, and BF\%, and the morphometric and ultrasound measurements was found (Table 6).

Since the age of the horses of the study was found to be positively correlated with $\mathrm{BF} \%(\mathrm{r}=0.90 ; p=0.001)$, the respective information was distributed according to the relevant age groups (youth -2 to 6 years, adults

Table 1 - Distribution of the study population of Colombian Paso horses, according to gait and gender $(n=69)$

\begin{tabular}{ccccc}
\hline Gender/Gait & Trot & Trocha & Paso Fino & Total \\
\hline Female & 10 & 16 & 13 & 39 \\
Male & 10 & 11 & 9 & 30 \\
Total & 20 & 27 & 22 & 69 \\
\hline
\end{tabular}

Table 2 - Morphometric and ultrasound measurements obtained from the study population of Colombian Paso horses $(\mathrm{n}=69)$

\begin{tabular}{lccc}
\hline \multicolumn{1}{c}{ Variable } & \multirow{2}{*}{ Mean } & \multicolumn{2}{c}{ Minimum } \\
& & Malue & value \\
\hline Circumference of the neck [cm] & $99.1 \pm 9.4$ & 61 & 114 \\
Perimeter of the thorax [cm] & $163.7 \pm 7.9$ & 138 & 193 \\
Chest width [cm] & $34.2 \pm 4.0$ & 24 & 44 \\
Body length [cm] & $154.2 \pm 10.9$ & 138 & 216 \\
Height at the withers [cm] & $138.6 \pm 3.2$ & 130 & 148 \\
Weight [kg] & $350.7 \pm 36.2$ & 268 & 486 \\
SFT-75\% of neck length [mm] & $7.5 \pm 2.3$ & 2.1 & 13.4 \\
SFT-lumbar region [mm] & $7.0 \pm 2.2$ & 3.2 & 13.2 \\
SFT-gluteal region [mm] & $7.1 \pm 2.1$ & 3.4 & 14 \\
Gluteus muscle thickness [mm] & $77.3 \pm 12.2$ & 42.2 & 98.9 \\
Body fat percentage & $6.4 \pm 1.1$ & 4.3 & 10.1 \\
\hline SFT = Subcutaneous fat thickness. & & &
\end{tabular}

-6 to 10 years, and seniles $\rightarrow 10$ years (Table 7). Similarly, since the weight was found to be positively correlated with $\mathrm{BF} \%(\mathrm{r}=0.82 ; p=0.038)$, the corresponding information is presented according to the groups of relevance (Table 8 ). Table 9 shows the non-significant results found in ultrasound measurements and $\mathrm{BF} \%$ according to gender.

\section{Discussion}

Ultrasonography has become an important and objective method for the evaluation of regional fat distribution since it allows independent estimation of the subcutaneous adipose tissue. This method is technically limited in areas with large amounts of connective tissue within adipose tissue (e.g. nuchal crest), because there is a very discrete limit that separates adipose tissue and muscle, affecting the ultrasound reading (Martin-Giménez et al., 2016a). This situation was confirmed in the present study, since an important number of horses of the study population $(n=35)$ showed Carter's nuchal crest scoring of 4 and 5, making it difficult to carry out the measurements in this anatomical area. It is important to consider that ultrasonographic image contrast between body tissues is essential and must be guaranteed through the frequency of the transducer, as well as the selection of an anatomical location, where it is feasible to discern the density of each tissue layer. In the present study, the lumbar region and gluteal region SFT measurements were determined to be the most appropriate locations for ultrasonographic evaluation in $\mathrm{CPHs}$. On the other hand, from a practical point of view, this kind of ultrasound does not require sedation, in addition to the fact that it is not necessary to shave the animal's skin or to use difficult-to-clean substances such as ultrasound gel.

Jensen et al. (2016) found that neither age nor gender had an effect on BCS or associated morphometric measures. In the present study, this finding was also found for gender. However, it was also established that age was positively correlated with $\mathrm{BF} \%(p=0.001)$, within $<10$ years-old animals included in the present study —an obesity-predisposed age group. Meanwhile, gait did not influence the results.

Table 3 - Mean and standard deviation ( $\mathrm{SD} \pm$ ) for ultrasound measurements, the circumference of the neck, ultrasound measurements, body fat percentage $(\mathrm{BF} \%)$, and body mass index (BMI), according to Henneke's body condition score (BCS) in the study population of Colombian Paso horses $(n=69)$

\begin{tabular}{cccccccc}
\hline Henneke's BCS & $\begin{array}{c}\text { Circumference of } \\
\text { the neck [cm] }\end{array}$ & $\begin{array}{c}\text { SFT-75\% of neck } \\
\text { length [mm] }\end{array}$ & $\begin{array}{c}\text { SFT-lumbar } \\
\text { region [mm] }\end{array}$ & $\begin{array}{c}\text { SFT-gluteal } \\
\text { region [mm }]^{\text {bt }}\end{array}$ & BF\% & BMI [kg/m ${ }^{2}$ & $\mathbf{n}$ \\
\hline $3 / 9$ & $90 \pm 11$ & $3.7 \pm 2.2$ & $4.0 \pm 1.1$ & $4.7 \pm 1.8$ & $5.0 \pm 1.0$ & $157 \pm 0.0$ & 2 \\
$5 / 9$ & $87 \pm 27$ & $6.1 \pm 1.5$ & $5.1 \pm 0.1$ & $5.7 \pm 0.1$ & $5.6 \pm 0.0$ & $171 \pm 0.0$ & 2 \\
$6 / 9$ & $93 \pm 14$ & $6.6 \pm 1.7$ & $6.3 \pm 2.0$ & $5.6 \pm 1.3$ & $5.5 \pm 0.7$ & $172 \pm 11$ & 8 \\
$7 / 9$ & $99 \pm 7.3$ & $7.5 \pm 2.2$ & $7.2 \pm 2.2$ & $7.1 \pm 1.8$ & $6.3 \pm 1.0$ & $178 \pm 13$ & 32 \\
$8 / 9$ & $103 \pm 6.3$ & $8.1 \pm 2.3$ & $7.4 \pm 2.2$ & $7.9 \pm 2.3$ & $6.8 \pm 1.2$ & $194 \pm 15$ & 25 \\
\hline
\end{tabular}

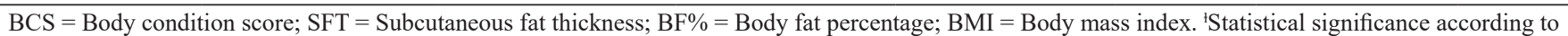
ANOVA analysis $(\mathrm{p} \leq 0.05) ;{ }^{\mathrm{a}} \mathrm{p}=0.0042 ;{ }^{\mathrm{b}} \mathrm{p}=0.0127$. 
Table 4 - Morphometric measurements according to Henneke's body condition score (BCS; mean and $\mathrm{SD} \pm$ ) in the study population of Colombian Paso horses $(n=69)$

\begin{tabular}{ccc}
\hline Henneke's BCS & GC:HW mean & NC:HW mean \\
\hline $3 / 9$ & $1.12 \pm 0.01$ & $0.63 \pm 0.03$ \\
$5 / 9$ & $1.15 \pm 0.02$ & $0.62 \pm 0.18$ \\
$6 / 9$ & $1.16 \pm 0.03$ & $0.67 \pm 0.10$ \\
$7 / 9$ & $1.18 \pm 0.04$ & $0.72 \pm 0.05$ \\
$8 / 9$ & $1.20 \pm 0.06$ & $0.74 \pm 0.04$
\end{tabular}

$\mathrm{BCS}=$ Body condition score; $\mathrm{GC}: \mathrm{HW}=$ Girth circumference: height at withers ratio; $\mathrm{NC}: \mathrm{HW}=$ Neck circumference: height at withers ratio.

Table 5 - Mean of the calculated values for morphometric measurements, according to gait and gender in the study population of Colombian Paso horses $(n=69)$

\begin{tabular}{cccc}
\hline & GC:HW & NC:HW & BF\% \\
\hline Trot & & & \\
Female & 1.21 & 0.71 & 6.2 \\
Male & 1.16 & 0.74 & 6.8 \\
Trocha & & & \\
Female & 1.19 & 0.69 & 6.5 \\
Male & 1.16 & 0.73 & 6.1 \\
Paso Fino & & & \\
Female & 1.18 & 0.69 & 6.2 \\
Male & 1.18 & 0.76 & 6.3 \\
\hline
\end{tabular}

GC:HW = Girth circumference: height at withers ratio; NC:HW = Neck circumference: height at withers ratio; $\mathrm{BF} \%=$ Body fat percentage.

Table 6 - Correlation results between Henneke's body condition score (BCS), body mass index (BMI) and body fat percentage $(\mathrm{BF} \%)$, and the morphometric and ultrasound measurements in the study population of Colombian Paso horses $(n=69)$

\begin{tabular}{lccc}
\hline & Categories & r-value & p-value* \\
\hline Henneke's BCS & Circumference of the neck & 0.77 & 0.012 \\
& The perimeter of the thorax & 0.66 & 0.008 \\
& Height at the withers & 0.62 & 0.050 \\
$\mathrm{BMI}$ & NC:HW ratio & 0.62 & 0.045 \\
$\mathrm{BF} \%$ & Age & 0.90 & 0.001 \\
& Weight & 0.82 & 0.038 \\
& SFT-lumbar region & 0.78 & 0.000 \\
& SFT-gluteal region & 0.76 & 0.000 \\
\hline
\end{tabular}

$\mathrm{BCS}=$ Body condition score BMI $=$ Body mass index; $\mathrm{NC}: \mathrm{HW}=$ Neck circumference: height at withers; $\mathrm{BF} \%=$ Body fat percentage; $\mathrm{SFT}=$ Subcutaneous fat thickness. *Statistical significance according to Pearson analysis $(p \leq 0.05)$.

Table 7 - Mean and standard deviation $(\mathrm{SD} \pm$ ) of the body fat percentage $(\mathrm{BF} \%)$ according to the age group in the study population of Colombian Paso horses $(n=69)$

\begin{tabular}{ccccc}
\hline Age [years] & BF\% mean & $\begin{array}{c}\text { Minimum } \\
\text { value }\end{array}$ & $\begin{array}{c}\text { Maximum } \\
\text { value }\end{array}$ & $\mathbf{n}$ \\
\hline 2 to 6 & $6.4 \pm 1.0$ & 29 & 66 & 27 \\
6 to 10 & $6.4 \pm 1.2$ & 21 & 79 & 32 \\
$>10$ & $6.0 \pm 1.3$ & 23 & 60 & 10 \\
\hline
\end{tabular}

$\mathrm{BF} \%=$ Body fat percentage.

Our findings indicated that weight was positively correlated with $\mathrm{BF} \%(p=0.038)$. It seems that $\mathrm{CPHs}$ exceeding $351 \mathrm{~kg}$ of BW are mostly prone to deposit adipose tissue regardless of their gait. This effect may be due to the morphological
Table 8 - Mean and standard deviation $(\mathrm{SD} \pm$ ) of the body fat percentage $(\mathrm{BF} \%)$ according to the weight in the study population of Colombian Paso horses $(n=69)$

\begin{tabular}{ccccc}
\hline Weight [kg] & BF\% mean & $\begin{array}{c}\text { Minimum } \\
\text { value }\end{array}$ & $\begin{array}{c}\text { Maximum } \\
\text { value }\end{array}$ & $\mathbf{n}$ \\
\hline$\leq 300$ & $5.8 \pm 0.6$ & 29 & 43 & 4 \\
$301-350$ & $6.0 \pm 0.9$ & 21 & 66 & 38 \\
$\geq 351$ & $6.9 \pm 1.3$ & 27 & 79 & 27 \\
\hline BF\% = Body fat percentage. & &
\end{tabular}

Table 9 - Mean and standard deviation ( $\mathrm{SD} \pm$ ) of the subcutaneous fat thickness (SFT) and the body fat percentage $(\mathrm{BF} \%)$ according to gender in the study population of Colombian Paso horses $(n=69)$

\begin{tabular}{lccc}
\hline & $\begin{array}{c}\text { Females } \\
(\mathbf{n}=\mathbf{3 9})\end{array}$ & $\begin{array}{c}\text { Males } \\
(\mathbf{n = 3 0 )}\end{array}$ & $\boldsymbol{p}$-value* \\
\hline SFT-75\% of neck length & $6.83 \pm 1.93$ & $8.29 \pm 2.41$ & 0.164 \\
SFT-lumbar region & $7.16 \pm 2.27$ & $6.84 \pm 2.13$ & 0.481 \\
SFT-gluteal region & $7.03 \pm 2.16$ & $7.21 \pm 1.94$ & 0.221 \\
Gluteus muscle thickness & $74.53 \pm 12.51$ & $80.94 \pm 11.06$ & 0.409 \\
BF\% & $6.32 \pm 1.18$ & $6.41 \pm 1.06$ & 0.541 \\
\hline SFT = Subcutaneous fat thickness; BF\% $\%$ Body fat percentage. *Statistical \\
significance according to Pearson analysis $(p \leq 0.05)$.
\end{tabular}

characteristics of these animals concerning other breeds of saddle horses since they are usually small and in turn, do not have the body capacity to cumulate a greater component of muscle mass. It is important to define further study approaches on gait effect since morphologically, the appearance of the individual can change from one to another (e.g. different height and neck size) for the breed object of this study.

The Henneke's BCS is subjective by default and may result in underestimation of the horse's condition when the person who values it is not an expert, as verified by Jensen et al. (2016) in a study on 254 icelandic horses. Other ratios such as GC: HW and NC: HW should not be applied interchangeably in all breeds since racial morphometric differences and those due to gender dimorphism could modify the results. Besides, although both increased with Henneke's BCS, when the category corresponded to $7 / 9,8 / 9$, or $9 / 9$, they were not differentiable, making it impossible to discriminate between overweight and obese animals.

According to previous studies, a horse or pony is considered overweight (Henneke's BCS $\geq 7 / 9$ ) when the GC: $\mathrm{HW}$ is $\geq 1.26$ and $\geq 1.33$, respectively. While the NC: HW is used, a horse or pony is considered obese when the value is $\geq 0.63$ and $\geq 0.68$, respectively (Carter et al., 2009; Jensen et al., 2016). However, this assessment was not the same for the CPHs in the present study, since the NC: HW was higher than 1.26 when the Henneke's BCS was $\geq 3 / 9$ and, on the contrary, the GC: HW was lower than 1.20 in all the Henneke's BCS categories. Even though some studies have determined that all chest circumference-related morphometric measures are highly associated with Henneke's BCS (Donaldson et al., 
2004), the result of such study highlighted that the morphometric differences between breeds do not allow the transfer of all the methods for body fat evaluation, without being previously validated. Also, gender dimorphism in the horse involves changes in neck circumference and size of the animal; therefore, it must be taken into account when using a method in horses, independent of gender.

The BMI mean found in the present study was $183.98 \mathrm{~kg} / \mathrm{m}^{2}$, which is lower than the mean index found in ponies $\left(212.14 \mathrm{~kg} / \mathrm{m}^{2}\right)$ (Dugdale et al., 2011a) and to the mean found in athletic horses $\left(215 \mathrm{~kg} / \mathrm{m}^{2}\right)$ (Thatcher et al., 2008). This index is not very sensitive to determine body composition since it can only indicate the amount of mass per unit area and differs strongly between horse breeds. As evidenced in the results of the present study, BMI appears differentiable in the extreme categories of Henneke's BCS and BF\%, so it is not a sensitive indicator to determine adiposity in CPHs.

A study by Silva et al. (2016) determined that SFT measurement on the back at the level of the L3 was correlated with body condition in donkeys and horses, with a correlation coefficient greater than 0.7 . In contrast, the present study found that SFT on the lumbar area is correlated to BF\% $(p=0.000)$, despite not being reflected on Henneke's BCS results. On the other hand, Quaresma et al. (2013) reported a positive correlation between the SFT measurement on the back, ribs, and haunch and Henneke's BCS and, therefore, both methods should be used to define obesity in donkeys. Similar findings are reported herein, where Henneke's BCS rating was found to be an approximation tool in the definition of body composition, which in turn must be carried out in detail to determine the degree of body adiposity.

Manso-Filho et al. (2009) used a formula developed by Westervelt et al. (1976), considering the same anatomical reference point in the gluteal region. However, the constant values differ from those presented in this study. The formula used to estimate the $\mathrm{BF} \%$ was the result of the comparison between the ultrasound measurement of the gluteal muscle and the total ether extractable body fat carried out on pony carcasses $\left(r^{2}=0.93\right)$. By this calculation, the $B F \%$ appears to be higher than the one calculated using the formula of Kane et al. (1987). It should be considered that, by the time both methods were developed, the resolution of the ultrasound image was not high and allowed errors in the SFT measurement. Compared with other similar studies, the calculation proposed by Kane et al. (1987) seems to underestimate the BF\% (Manso-Filho et al., 2009; Silva et al., 2016).

Manso-Filho et al. (2009) found that stallions resulted in a higher BF\% (16.63 \pm 1.24$)$ compared to non-pregnant mares
$(13.95 \pm 0.92)$ and foals under 18 months $(10.38 \pm 0.26)$. Also, the type of physical activity performed by the animals represented significant differences in BF\% when dairy- was compared with show-working (10.82 vs. $14.77 \%$, respectively). In studies on thoroughbred foals and fillies up to 2 years of age, females were found to contain fatter tissue than males (Gee et al., 2003). However, when compared to the results of the present study, no gender-related differences in BF\% were found. This result was perhaps due to the differences between the age groups within each group (females and males).

It is interesting to explore other methods that do not require the use of any tool other than the conventional tape measure, as the study by Potter et al. (2015), where it was possible to obtain a modified Henneke's BCS (named body score index), using the following formula: $\mathrm{BCI}=\left[\right.$ chest circumference $\mathrm{e}^{0.5}$ + abdomen perimeter + neck circumference $\left.{ }^{1.2}\right) /$ height $\left.^{1.05}\right)$ ]. This calculation was correlated with $\mathrm{BF} \%$, measured using the deuterium dilution method $\left(\mathrm{r}^{2}=0.772\right)$. Such a method was already validated by Dugdale et al. (2011b), with a high correlation level, using the total white adipose tissue in cadavers $\left(r^{2}=0.97\right)$. Gee et al. (2003) also found an important correlation between adipose tissue predicted by ultrasound in live thoroughbred foals and fillies and adipose tissue effectively dissected post-mortem $(p=0.002)$.

Despite being discussed in multiple studies, Henneke's BCS is a complementary visual tool that can facilitate the assessment of obese animals. In a study conducted in a group of mares with extreme BCS (very thin vs. obese), it was determined that fat tissue thickness measured by ultrasound in the back, ribs, and neck was correlated with Henneke's BCS results. This was given to each animal, demonstrating that, for the most extreme scores on the scale, it is feasible to determine adipose tissue deposition. Furthermore, they found that the most sensitive location is the base of the tail (Gentry et al., 2004). From this information and the results of the present study, it can be inferred that both the measurement of adipose tissue by ultrasound and Henneke's BCS assessment, age, and weight are useful complementary variables for the evaluation of the body's adiposity in CPHs.

\section{Conclusion}

From a general point of view, the assessment of the body composition in the horse must involve a set of non-invasive methods, obtaining the greatest amount of data related to the deposition of adipose tissue. This is important since it has been shown that fat deposition patterns can be different, depending on the anatomical location, physical activity, and genetic predisposition of the animal. According to our results, the evaluation of the body composition in the $\mathrm{CPHs}$ must be 
composed by the Henneke's BCS assessment (with special emphasis on the base of the tail), SFT-lumbar region and/or SFT-gluteal region measurement, determination of the $\mathrm{BF} \%$, and differentiation by age and body weight. The regional adiposity of the neck should be explored independently since it was not found as a determining factor in the evaluation of overweight or obesity in CPHs in the present study.

\section{Conflict of Interest}

The authors state that they have no conflicts of interest to declare.

\section{References}

Argo CM, Curtis GC, Grove-White D, Dugdale AHA, Barfoot CF, Harris PA. Weight loss resistance: a further consideration for the nutritional management of obese Equidae. Vet J. 2012;194(2):179-88. http://dx.doi.org/10.1016/j. tvjl.2012.09.020. PMid:23117030.

Carter RA, Geor RJ, Burton Staniar W, Cubitt TA, Harris PA. Apparent adiposity assessed by standardized scoring systems and morphometric measurements in horses and ponies. Vet J. 2009;179(2):204-10. http://dx.doi.org/10.1016/j. tvjl.2008.02.029. PMid:18440844.

Donaldson MT, McFarlane D, Jorgensen AJ, Beech J. Correlation between plasma a-melanocyte-stimulating hormone concentration and body mass index in healthy horses. Am J Vet Res. 2004;65(11):1469-73. http://dx.doi. org/10.2460/ajvr.2004.65.1469. PMid:15566082.

Dugdale AH, Curtis GC, Harris PA, Argo CM. Assessment of body fat in the pony: part I. Relationships between the anatomical distribution of adipose tissue, body composition and body condition. Equine Vet J. 2011a;43(5):552-61. http://dx.doi.org/10.1111/j.2042-3306.2010.00330.x. PMid:21496091.

Dugdale AH, Curtis GC, Milne E, Harris PA, Argo C. Assessment of body fat in the pony: part II. Validation of the deuterium oxide dilution technique for the measurement of body fat. Equine Vet J. 2011b;43(5):562-70. http://dx.doi. org/10.1111/j.2042-3306.2010.00327.x. PMid:21496088.

Gee E, Fennessy P, Morel P, Grace N, Firth E, Mogg T. Chemical body composition of 20 Thoroughbred foals at 160 days of age, and preliminary investigation of techniques used to predict body fatness. N Z Vet J. 2003;51(3):125-31. http://dx.doi.org/10.1080/00480169.2003.36351.

\section{Ethics Statement}

The Ethics Committee for Animal Experimentation of the University of Antioquia (Medellín, Colombia) approved all the procedures performed on the animals of the present study (Act \#122, February $5^{\text {th }}, 2018$ ).

\section{Acknowledgements}

To Normandía Equine Center, veterinary medicine undergraduate students (University of Antioquia), and to Carlos Brand (horse rider), who provided the animals, facilities, and support for data collection.

Gentry LR, Thompson DL Jr, Gentry GT Jr, Del Vecchio RP, Davis KA, Del Vecchio PM. The relationship between body condition score and ultrasonic fat measurements in mares of high versus low body condition. J Equine Vet Sci. 2004;24(5):198-203. http://dx.doi.org/10.1016/j. jevs.2004.04.009.

Henneke DR, Potter GD, Kreider JL, Yeates BF. Relationship between condition score, physical measurements and body fat percentage in mares. Equine Vet J. 1983;15(4):371-2. http://dx.doi.org/10.1111/j.2042-3306.1983.tb01826.x. PMid:6641685.

Hunka M, Cordeiro Manso H, Bernardo R, da Silva E, Ferreira L, Manso-Filho H. Development and body composition of Quarter horse foals during nursing. Open J Vet Med. 2014;4(11):276-80. http://dx.doi.org/10.4236/ ojvm.2014.411033.

Jensen RB, Danielsen SH, Tauson AH. Body condition score, morphometric measurements and estimation of body weight in mature Icelandic horses in Denmark. Acta Vet Scand. 2016;58(1, Suppl 1):59. http://dx.doi.org/10.1186/ s13028-016-0240-5. PMid:27766968.

Kane RA, Fisher M, Parrett D, Lawrence LM. Estimating fatness in horses. In Proceedings of the 10th Equine Nutrition and Physiology Symposium; 1987; Colorado. Colorado: Equine Nutrition and Physiology Society; 1987. 127. p.

Manso-Filho HC, Cordeiro Manso H, Ferreira LMC, Santiago TA, Wanderley EK, Abreu JMG. Percentagem de gordura de cavalo criados em região tropical. Acta Sci Vet. 2009;37(3):239-43. http://dx.doi.org/10.22456/16799216.16336. 
Martin-Giménez T, Aguirre-Pascasio CN, De Blas I. Development of an index based on ultrasonographic measurements for the objective appraisal of body condition in Andalusian horses. Span J Agric Res. 2018;15(4):6-9. http://dx.doi.org/10.5424/sjar/2017154-11732.

Martin-Giménez T, Aguirre-Pascasio CN, de Blas I. Ultrasonographic assessment of regional fat distribution and its relationship with body condition in an easy keeper horse breed. J Equine Vet Sci. 2016a;39:69-75. http://dx.doi. org/10.1016/j.jevs.2016.01.010.

Martin-Gimenez T, Blas I, Aguilera-Tejero E, Diez de Castro E, Aguirre-Pascasio CN. Endocrine, morphometric, and ultrasonographic characterization of neck adiposity in Andalusian horses. Domest Anim Endocrinol. 2016b;56:5762. http://dx.doi.org/10.1016/j.domaniend.2016.02.003. PMid:27088603.

Martinson KL, Coleman RC, Rendahl AK, Fang Z, McCue ME. Estimation of body weight and development of a body weight score for adult equids using morphometric measurements. J Anim Sci. 2014;92(5):2230-8. http://dx.doi. org/10.2527/jas.2013-6689. PMid:24663191.

Pearson W, Wood K, Stanley S, MacNicol J. Exploring relationships between body condition score, body fat, activity level and inflammatory biomarkers. J Anim Physiol Anim Nutr. 2018;102(4):1062-8. http://dx.doi.org/10.1111/ jpn.12893. PMid:29707811.

Potter SJ, Harris PA, Bailey SR. Derivation of a new body condition index to estimate body fat percentage from morphometric measurements: comparison with body condition score. J Equine Vet Sci. 2015;35(5):400-17. http:// dx.doi.org/10.1016/j.jevs.2015.03.073.
Quaresma M, Payan-Carreira R, Silva SR. Relationship between ultrasound measurements of body fat reserves and body condition score in female donkeys. Vet J. 2013;197(2):329-34. http://dx.doi.org/10.1016/j.tvjl.2012.12.031. PMid:23395347.

Silva SR, Payan-Carreira R, Quaresma M, Guedes CM, Santos AS. Relationships between body condition score and ultrasound skin-associated subcutaneous fat depth in equids. Acta Vet Scand. 2016;58(1, Suppl 1):62. http:// dx.doi.org/10.1186/s13028-016-0243-2. PMid:27766985.

StataCorp. Stata Statistical Software: Release 16. College Station, TX: StataCorp LLC; 2019.

Thatcher CD, Pleasant RS, Geor RJ, Elvinger F, Negrin KA, Franklin J, Gay L, Werre SR. Prevalence of obesity in mature horses: an equine body condition study. J Anim Physiol Anim Nutr. 2008;92(2):222. http://dx.doi. org/10.1111/j.1439-0396.2007.00789_8.x.

Velásquez-Mosquera JC, Mendoza-Sánchez G, CorralesÁlvarez JD, Parra-Pineda MA, Medina Rodríguez AC, Izquierdo Sánchez CD, González Acosta JP. Asociación de medidas morfométricas con grasa en el anca en caballos de salto en una escuela ecuestre de Bogotá. Rev Med Vet. 2016;(32):67-77. http://dx.doi.org/10.19052/mv.3856.

Westervelt RG, Stouffer JR, Hintz HF, Schryver HF. Estimating fatness in horses and ponies. J Anim Sci. 1976;43(4):781-5. http://dx.doi.org/10.2527/jas1976.434781x.

Financial Support: This work was supported by the Centauro research group, University of Antioquia (Medellín, Colombia) [Sustainability Strategy, 2018-2019]. 